\title{
EFFECT OF FOLIAR AND SOIL APPLICATION OF SOME RESIDUALS OF SUGAR CANE PRODUCTS (MOLASSES AND VINASSES) WITH MINERAL FERTILIZER LEVELS ON GROWTH, YIELD AND QUALITY OF SWEET PEPPER
}

\author{
Mona S. Gaafar, Nahed M. M. EL-Shimi and M. M. Helmy \\ Veg. Res. Dep., Hort. Res. Inst., Agric. Res. Center, Giza, Egypt \\ Received: Jul. 8,2019 \\ Accepted: Aug. 21, 2019
}

\begin{abstract}
The present study was carried out to determine the effect of some residuals of sugar cane products i.e., molasses and vinasses on the vegetative growth, yield and quality of sweet pepper (Capsicum annuum L.) cv. California Wonder in the Experimental Farm of Kaha research Station, Qalubia Governorate during two summer seasons of 2017 and 2018 years were studied. The experiment was set up using splitplot design with three replicates where the fertilization rates with three percents $(50 \%$, $75 \%$ and $100 \%$ ) from the recommended mineral fertilization of sweet pepper were assigned in the main plots, while the foliar and the soil application of molasses and vinasses with two rates ( $4 \%$ and $6 \%$ as foliar spray) and applied to soil with two rates $(60$ and $120 \mathrm{~L} /$ fed.) were distributed in the sub plots. The results of this study indicate that, the highest rates from recommended mineral fertilization $75 \%$ and $100 \%$ compared with $50 \%$ showed significant increase on the vegetative growth characters, yield and its component as well as fruit quality. Concerning to the influence of the treatments of foliar spray or soil application of molasses and vinasses recorded significant differences increases on the vegetative growth characters $i$. e.; plant length, stem diameter, number of branches and leaves / plant, leaf area/plant and dry weight of plant as well as fruit characters and fruit yield with best quality in both growing seasons. The best treatments were the highest rates from molasses or vinasses (6\% as foliar spray) or obtained from using (120 L/ fed. as soil application) compared with the other treatments. Regarding to the interactions between mineral fertilization levels and foliar spray or soil application of molasses and vinasses. The same data clear significant effect of the previous treatment on all vegetative growth parameters and fruits yield with best quality of sweet pepper plants. The superior values were observed with $75 \%$ and100 \% of the recommended mineral fertilization with adding molasses or vinasses either soil application at the rates of 60 or 120 L/fed or foliar spray at rate of $6 \%$ comparing to mineral fertilizer alone.
\end{abstract}

Generally it can said that, addition of some residuals of sugar cane products $i$. e., molasses or vinasses improved the vegetative growth and fruits yield with best quality of sweet pepper plants compared with the control (mineral fertilization only) and save $25 \%$ from the fertilizer recommendation and recognized the highest benefit cost ratio.

Key words: Sweet pepper, mineral fertilizer, molasses, vinasses, fruits yield, quality .

\section{INTRODUCTION}

In Egypt, sweet pepper (Capsicum annuum L.) is one of the most popular and favorite vegetable crop cultivated for local market and exportation. Pepper consider is the third important crop of Solanaceae family after tomatoes and potatoes. It is a valuable food, rich in antioxidants, vitamins and minerals. So, sweet pepper has occupied an important rank in Egyptian and world agriculture due to its high profit and nutritional values for human health (Mengel and 
Kirkby (1982) and Rajput and Poruleker, 1998).

As a general the plants require nitrogen, phosphor and potassium as a certain mineral nutrients to grow and to produce yield, the pepper plants require largest quantities from its and some of these fertilizer losses through the soil, in addition availability of nutrient has been reported to be directly related to yield (Roberts, 2001). Devi et al. (2002) obtained better fruit weight and fruit yield of eggplant with the application of $120 \mathrm{~kg}$ (NPK) per hectare. Also Doss el al. (2015) revealed that the gradual increases of NPK fertilizer levels were accompanied with significant increases on sweet potato growth, yield and its components.

Recently, the high cost of fertilizers and concerns about environmental protection have been great incentives to focus on the possibility of using natural and safe agents for promoting growth and yield of vegetable crops, for example, utilizing organic residues in agriculture contributes to the conservation of natural resources by recycling carbon and mineral elements. Such as the organic residues produced through manufacture of the sugar and alcohol agro-industries whereas have great potential for use its in conservation agriculture. The production of sugar and alcohol generates large quantities of bioproducts, such as vinasses, the quantity of vinasse production depends on the processing technique employed and also on the wine composition, which varying between 10 and 18 liters of vinasses per liter of alcohol production, it can be used it as soil improvers and substitutes for inorganic phosphorus and potassium fertilizers as mentioned by Silva et al. (2007) and Renato et al. (2013). Vinasses is an aqueous effluent of the distillation unit in the sugar-alcohol industry and it consider as problem to the sector and this due to producing high amounts of its and potential effects as an environmental pollutant. It is contain large amounts of water, organic matter, and mineral elements. The environmental damage caused by discharging vinasses into the soil or running waters causing big problem while it can using it as a economic applications for this residue as natural organic material and using its in agriculture. In this regard some investigators reported that, it can properly using vinasse contributes to improvement the soil quality Silva et al.( 2006) and Gemtos et al. (1999) and agricultural productivity Zolin et al. (2011) Madejon et al. (2001) and Paulino et al. (2002). Vinasses in natural case is a dilute solution and its application to soil directly reach to high quantities, causing more use difficult in the sites of production. However, vinasses can be concentrated by evaporation, resulting in a product with higher economic viability that can be transported to distant locations or to the sandy soil. It was found that the organic matter, $\mathrm{K}, \mathrm{N}, \mathrm{Ca}$, and $\mathrm{Mg}$ are the main chemical components of vinasses, $K$ being the most important mineral element for the agricultural. Therefore, vinasses is a source of nutrients, organic matter, and by adding it can contribute to increased productivity of sugar cane Resende et al . (2006), with positive effects on the chemical Silva et al. (2006), physical, Jiang et al. (2012), and biological Laime et al. (2011) on soil attributes, moreover, Li et al. (2008) and Mo et al. (2009) In China, found that sugar cane plants treated with vinasses has increased productivity and sucrose yields. Also, In Brazil, Zolin et al. (2011) and Paulino et al. (2002) reported that, at long-term application of vinasses (150 m $3 \mathrm{ha}-1$ year-1) in sugar cane production confirmed positive effects on productivity and increased potassium concentration in the soil. In Spain, 
Madejón (2001) found that the yields of beets and maize were compared after treatments with an organic compound based on vinasses or a mineral fertilizer; they found that the crop production was similar in both treatments indicating that the utilization of vinasse is a viable alternative for mineral fertilizers. Therefore, conservation practices, like the employment of residues in agriculture can contribute to increased agricultural productivity whilst minimizing environmental pollution.

Another residues it can producing it by the sugar agro-industries and using it in agriculture, this product is molasses. Molasses is the residual syrup from the processing of sugar beet and sugar cane (Honma et al., 2012). Molasses is produced annually in large amounts and were used in different industries including animal feeding, alcohol and fertilizers. The use of sugar beet molasses in agriculture stimulates nutrient elements uptake efficiency and soil biological contents because sugar beet molasses contains different amounts of humic, fulvic and amino acids (Samatav and Samatav, 2014). Humic and Fulvic acids have a significant effect on plant growth (Samatav and Samatav, 2014). The use of sugar beet molasses in agriculture is enhancing nutrient elements uptake efficiency and increasing soil biological activity. In sugar beet molasses, contain different amounts of humic, fulvic and amino acids. Fulvic acid due to the small molecular structure is more efficient to penetrate to the plant roots. Pujar (1995) reported that foliar application of molasses increased uptake of $\mathrm{Zn}, \mathrm{Cu}, \mathrm{Fe}$ and $\mathrm{Mn}$ in corn and wheat compared to the control. Chandraju (2008) reported that the using of a diluted solution of molasses will increase nutrient uptake and yield of leafy vegetables like cabbage. Mohammadi and Torkashv (2008) reported that using molasses increased total nitrogen, potassium and decreased unavailable phosphorus in the soil. It also, increased the growth of shoot length, leaf number per plant, leaf area and chlorophyll content of peas (Rani, and Vastava, 1990). Moreover, Şanlı et al. (2015) on sugar beet studied that, addition different concentrations of molasses to the soil and to the plant leaves at different doses $(0,25,50,75$ and $100 \mathrm{~kg} / \mathrm{ha}$ ) 3 times during the vegetation period, and found that, Molasses applications significantly increased root yield and its quality compared to the control, at the same time soil applications were more effective than foliar applications for all parameters studied. So that molasses can be used effectively in order to increase sugar beet yield and its quality.

Therefore, the objective of this work was to study influence of using some residuals of sugar cane manufacture (molasses and vinasses) as a soil or foliar application on growth, yield, and quality of sweet pepper and reflect of that on increasing fruit yield and minimizing mineral fertilization rates.

\section{MATERIALS AND METHODS}

The experiment was conducted at the Experimental Farm of Kaha, Qalubia Governorate, Egypt to investigate the effect of using molasses and vinasses as a soil or foliar application on growth, yield, and quality of sweet pepper (Capsicum annuum L. cv. California Wonder.) under three rates, i.e., (50\%, $75 \%$ and $100 \%$ ) from the recommended mineral fertilization of sweet pepper plants.

The present investigation was conducted during two successive summer seasons of 2017 and 2018. Seeds of sweet pepper (Capsicum annuum L. cv. California Wonder.) were sown under plastic house in nursery at the first week of February during both 
Mona S. Gaafar, et al.,

2017 and 2018 seasons and received the recommended agricultural practices of the nursery. After 50 days from seeds sowing, healthy seedlings were selected and transplanted in the open field at $35 \mathrm{~cm}$ apart between the seedlings in one side of the ridge $(4.0 \mathrm{~m}$ length and $0.7 \mathrm{~m}$ width). The plot area was $\left(8.4 \mathrm{~m}^{2}\right)$ which includes 3 ridges. The soil texture was clay characterized with the following characteristics: Coarse sand $13.9 \%$, Fine sand $9.1 \%$, Silt $26 \%$, Clay $51 \%$, Organic matter $1.66 \%, \mathrm{pH} 7.8, \mathrm{EC} \mathrm{dS} / \mathrm{m} 2.2$, available macronutrients (ppm): N 53.3, K 60.35, P 4.1, anions, $\mathrm{HCO}_{3}-3.5$, $\mathrm{CL}-11.0$, $\mathrm{SO}_{4}-2 \mathrm{C} .45$ and cations $\mathrm{Na}+8.8, \mathrm{Ca}+2$ 3.9, $\mathrm{Mg}+28.1$ and $\mathrm{K}+0.15$. Physical and chemical properties were analyzed as described by Piper (1950).

The experiment was set up using splitplot design with three replicates, whereas the fertilization rates $(50 \%, 75 \%$ and $100 \%$ ) from the recommended mineral fertilization of sweet pepper plants i.e., $130 \mathrm{~kg} \mathrm{~N}+45 \mathrm{~kg} \mathrm{P}_{2} \mathrm{O}_{5}+72 \mathrm{~kg} \mathrm{~K} 2 \mathrm{O} / \mathrm{fed}$, were assigned in the main plots, while the foliar and the soil application of molasses and vinasses with two rates
(4\% and $6 \%$ as foliar spray) and applied to the soil with two rates $(60$ and $120 \mathrm{~L} /$ fed.) which were distributed in the sub plots. Different concentrations of molasses and vinasses as mentioned were applied to the soil and to plant leaves as foliar spray 3 times during the vegetation period, the first time was at $\mathbf{3 0}$ days after transplanting and repeated each 15 days interval. The treatment of the residuals of sugar cane manufacture, i.e molasses and vinasses, which obtained that from El-Hawamidyah Integration Instruction Company (E S I I C). Its composition and its concentration are shown in Table (1) data was obtained from USDA nutrition table.

The experiment included 27 treatments, which were the combinations between the fertilization rates and molasses or vinasses treatments as follows:

\section{A-The main plots:}

Three rates of NPK $(50,75$ and $100 \%$ from the recommended mineral fertilization of sweet pepper plants (130 $\mathrm{kg} \mathrm{N}+45 \mathrm{~kg} \mathrm{P}_{2} \mathrm{O}_{5}+72 \mathrm{~kg} \mathrm{~K} \mathrm{O} /$ fed.)

Table (1): The compositions of the residuals of sugar can manufacture (molasses and vinasses)

\begin{tabular}{|c|c|c|}
\hline Constituent & Molasses & Vinasses \\
\hline Brix & 86.50 & 11.01 \\
pH & 5.01 & 4.31 \\
Ash (\%) & 39.5 & 25.00 \\
Ca (\%) & 1.58 & 4.06 \\
SO 4 mg/l & 19 & 14 \\
P (\%) & 0.3 & 0.24 \\
N (\%) & 0.61 & 0.47 \\
K (\%) & 1.5 & 1.6 \\
Dry matter & 66.8 & 29.31 \\
Protein\% & 3.81 & 2.92 \\
Reducing sugars (\%) & 24.9 & 4.43 \\
\hline
\end{tabular}


B-The sub plots, which contained the following nine treatments:

1- Control, which fertilized by the recommended mineral fertilization only.

2- Molasses foliar spray $4 \%$ (MF).

3- Molasses foliar spray $6 \%$ (MF).

4-Molasses soil application $60 \mathrm{~L} /$ fed. (MS) (It added through three times i.e., 30,45 and 60 days from transplanting).

5- Molasses soil application $120 \mathrm{~L}$ fed. (MS) (It added through three times i.e., 30,45 and 60 days from transplanting).

6-Vinasses foliar spray $4 \%$ (VS).

7 - Vinasses foliar spray $6 \%$ (VS).

8-Vinasses soil application 60 L/fed. (VS) (It added through three times i.e., 30, 45 and 60 days from transplanting).

9-Vinasse soil application 120 L/fed. (VS) (It added through three times i.e., 30, 45 and 60 days from transplanting).

\section{Data recorded:}

1- Vegetative growth parameters:

Three plants were chosen randomly from each sub plot treatments at the flowering stage (after 85 days from transplanting) in order to determine each of: plant height (the length of main stem $\mathrm{cm})$, stem diameter $(\mathrm{cm})$, number of leaves and branches /plant, leaf area/ plant as well as average plant dry weight (weights of leaves and stems/ plant (g).

The leaf area was calculated according to the following formula of Wallace and Munger (1965).

Leaf area $\left(\mathrm{cm}^{2}\right)=$ Leaves dry weight $(\mathrm{g}) \mathrm{x}$ disk area / disk dry weight (g)

\section{2- Fruit yield and its characteristics:}

Five sweet pepper fruits were randomly selected from each sub plot at the second picking to determine the following data:

Fruit length $(\mathrm{cm})$, fruit diameter $(\mathrm{cm})$, fruit flesh thickness $(\mathrm{cm})$, total soluble solids (TSS), average fruit weight (g) and dry matter percent in fruits. i.e $100 \mathrm{~g}$ from fruit was taken and dried at $70 \mathrm{C}^{\circ}$ till constant weight and the dry weight was determined - Number of fruits I plant, fruits yield / plant $(\mathrm{kg})$ and total fruits yield (ton/fed) were also estimated.

\section{3- Chemical properties:}

Total nitrogen, potassium and phosphor were determined in the dry fruits on the basis of dry weight according to the methods described by Bremner and Mulvaney (1982), Olsen and Sommers (1982) and Chapman and Pratt (1961), respectively.

Total ascorbic acid: (Vitamin C $\mathrm{mg} / 100 \mathrm{~g}$ fresh weight) content was determined using 2, 6 dichlorophenol indophenols pigment, as method described by Ranganna (1979).

Total leaf chlorophyll was measured using Minolta chlorophyll meter. SPAD501as SPAD units.

\section{4- Economic study:}

Economic performance of sweet pepper yield, i.e., gross return, treatment cost, total variable cost, net return and benefit-cost ratio were calculated based on market prices as average of the two seasons. The benefit-cost ratio was determined according to Boardman et al., (2001) by dividing the gross return (£E /fed)) on total variable cost (£E /fed).

\section{5- Statistical analysis:}

All data were subjected to the statistical analysis of variance and treatment means were compared according to the Least Significant Differences (L. S. D. at $5 \%$ level) test method as described by Snedecor and Cochran (1980).

\section{RESULTS AND DISCUSSION}

I- Effect of fertilization levels and foliar spray or soil application by some residuals of sugar cane 
Mona S. Gaafar, et al.,

products (molasses and vinasses) treatments on the vegetative growth:

\section{I.1 Effect of mineral fertilization rates:}

The vegetative growth characters which determined in this study i. e., plant height, stem diameter, number of leaves and branches/plant, leaf area/plant as well as plant dry weight of sweet pepper plants were affected by different rates of the recommended mineral fertilization as shown in Table (2). The data revealed that, all different fertilization rates of (NPK) recorded a significant increase on the vegetative growth parameters in both growing seasons of the study. The highest values were obtained when adding $100 \%$ followed by $75 \%$ of the recommended doses of mineral fertilization. Many investigators reported that increasing the amount of NPKfertilizer caused an increase in the vegetative growth of sweet pepper plants such as (Roberts, 2001) who reported that, as general the plants need nitrogen, phosphor and potassium as a certain mineral nutrients to grow and to produce yield, whereas its require its in the largest quantities.

I.2 Effect of foliar spray or soil application by some residuals of sugar cane products (molasses and vinasses) treatments:

The results in Table (2) show the vegetative growth parameters as affected by addition of molasses or vinasses either as foliar spray or as soil application. The data illustrated that, using the previous treatments recorded significant increases on the vegetative growth characters i. e.; plant length, stem diameter, number of branches and leaves I plant, leaves area/plant and dry weight of plant in both growing seasons when the plants were sprayed by molasses or vinasses with the two rates $(4 \%$ and $6 \%)$ or by soil application of molasses and vinasses with the two rates ( 60 and 120 L/ fed.) comparing to the control treatment which gave the lowest values. But, Soil applications were more effective than foliar applications for all studied parameters. While, the highest values were obtained with soil applications from molasses and vinasses especially with the highest rate $i$, e., $120 \mathrm{~L} /$ fed. The enhancing effect of vinasses may be due to its contain of several nutrients such as organic matter, $\mathrm{K}, \mathrm{N}, \mathrm{Ca}$, and $\mathrm{Mg}$ are the main chemical components of vinasses. (Silva, et al., 2006), with its effect on the physical, (Jiang et al., 2012), on the biological (Resende et al., 2013), on the chemical and (Laime et al., 2011) of the soil attributes. Another results indicate that, properly used, vinasses contributes to improvements the soil quality (Silva et al., 2006) and Gemtos et al. (1999) and agricultural productivity (Zolin et al. ,2011) Madejon et al., 2001) and Paulino et al., 2002).

In addition, using sugar beet molasses in agriculture enhancing nutrient elements uptake efficiency and soil biological activity increases because sugar beet molasses which its contains different amounts of humic, fulvic and amino acids as remembered by (Samatav and Samatav, 2014), Pujar,1995) and Chandraju, 2008).

1-3 Effect of the interactions between mineral fertilization rates and foliar spray or soil application by some residuals of sugar cane products (molasses and vinasses) on vegetative growth of sweet pepper plants:

Data illustrated in (Table 3) show the interactions between fertilization levels and foliar spray or soil application by some residuals of sugar cane products (molasses and vinasses) on the vegetative growth characters. It is clear 
要

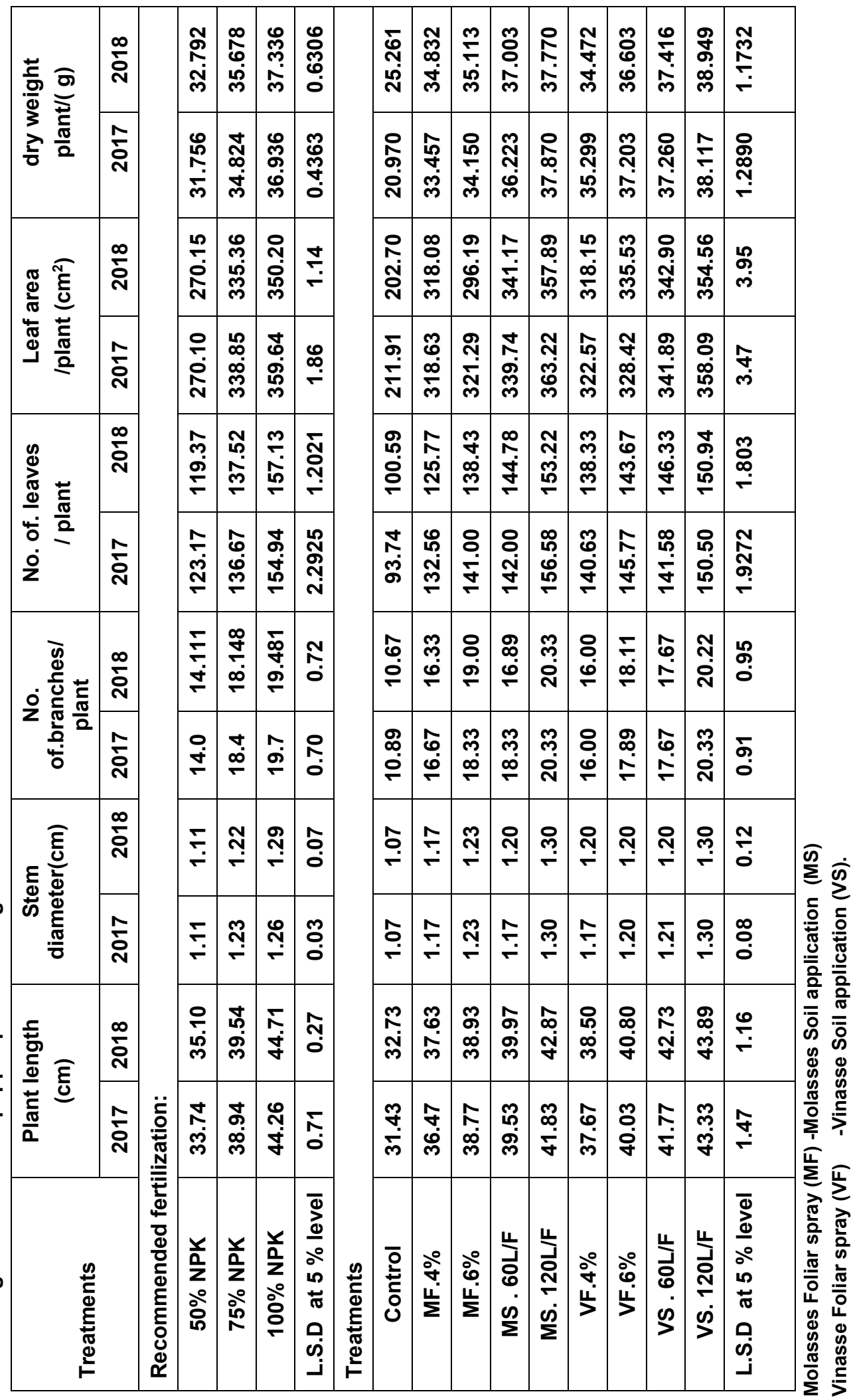


Mona S. Gaafar, et al.,

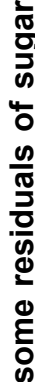

$\infty$ 원워

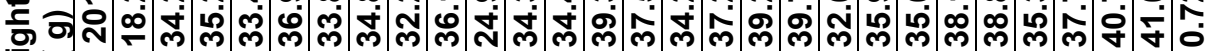
\索

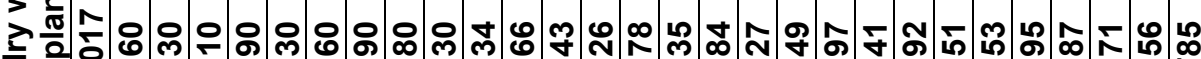
N - m

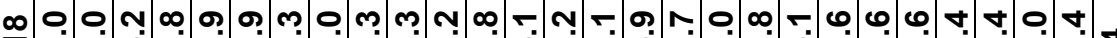

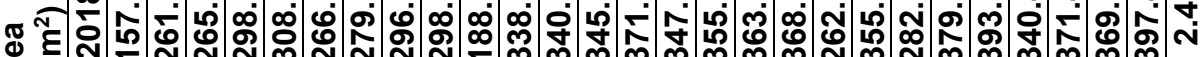
বำ

응ำ $\frac{10}{0}$



\section{के}

등 응

$\frac{10}{\pi}$

㝏

ธั

ते जे

을

ํㅡㅇ

岕

-

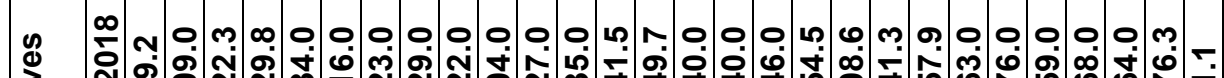

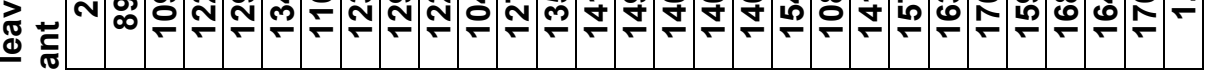

ப்

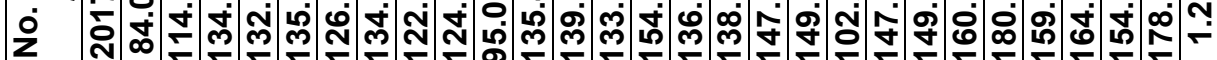

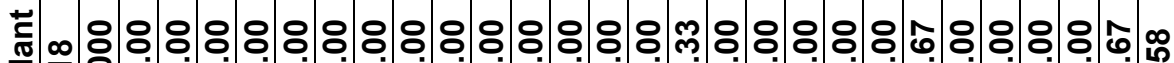

읃 돋

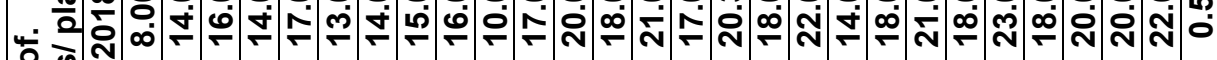

o :

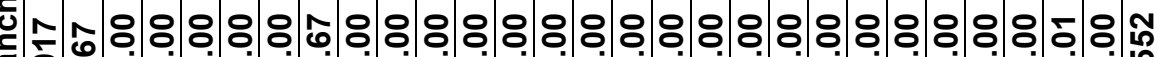

సั่

督

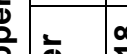

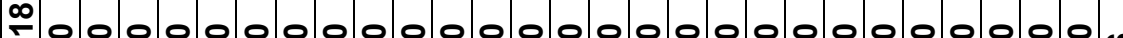

$\stackrel{0}{2}$

तั ฮั

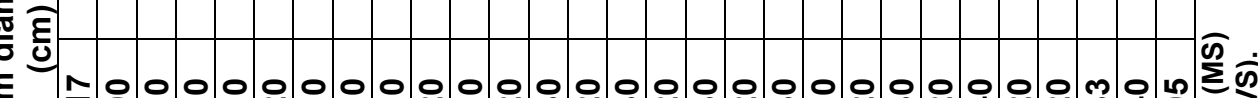

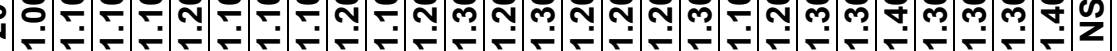

$\sum_{0}^{0}$

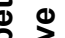

s

은

응

(0)

Ð

$=\stackrel{0}{0}$

을

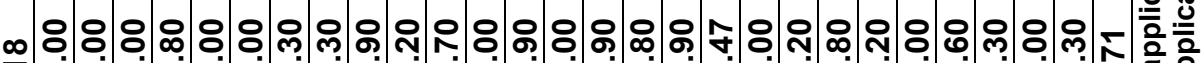

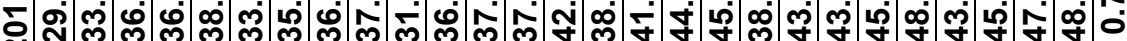
ह

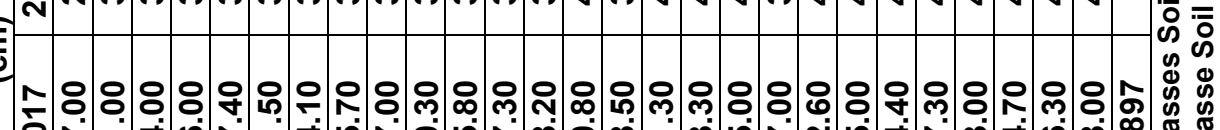

N N

ర วㅇํ 亲 రํํ

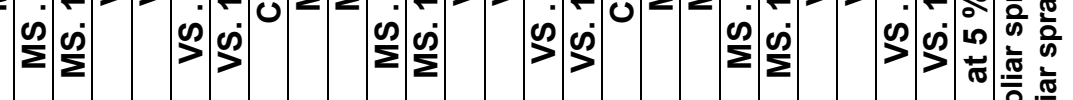

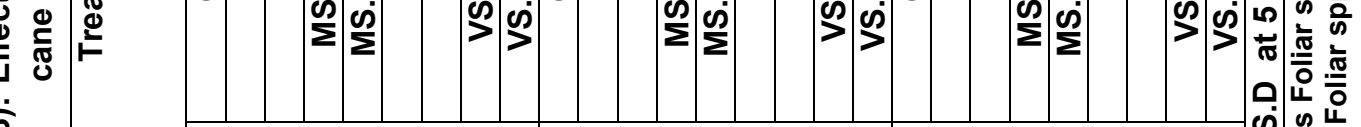

ले

$\frac{0}{0}$

uo!łez!!!นә」 YdN

$\% 0 S$

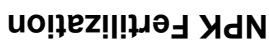

$\% S L$ uo!łez!!!น⿰习习 YdN $\% 00$ L 
that, the two materials in its combination induced significant effect on all vegetative growth parameters of sweet pepper plant i.e., plant length, number of branches and leaves I plant, leaves area/plant and dry weight/ plant except stem diameter in the second growing season. The superior values of vegetative growth were observed from the combination of $75 \%$ and $100 \%$ of the recommended mineral fertilization with soil application of molasses at the rate of 60 or $120 \mathrm{~L} / \mathrm{fed}$ and vinasses at the rate of 60 or $120 \mathrm{~L} / \mathrm{fed}$, comparing to fertilizer additions alone (control).

II - Effect of mineral fertilization rates and foliar spray or soil application by some residuals of sugar cane products (molasses and vinasse) on the fruit characters of sweet pepper plants.

\section{II.1 Effect of mineral fertilization rates:}

Data in Table (4) show that, the statistical analysis at $(p<0.05)$ reveal that the increasing fertilization rates from the low level to the highest one has a significant effect on the fruit quality characters of sweet pepper, i.e., fruit length, fresh fruit weight in both seasons. While fruit diameter and dry matter in the fruit were significant in the second season but not reach to significant level in the first season. T.S.S in the fruit not reached to significant level in the second season, while the flesh fruit thicknesses not reach to significant level in both season. This result are in the same line with Devi et al. (2002) obtained better fruit weight and fruit yield of eggplant with the application of $120 \mathrm{~kg}$ (NPK) per hectare. Also Doss el al. (2015) revealed that the gradual increases of NPK fertilizer levels were accompanied with significant increases on sweet potato yield and its components.
II.2 Effect of foliar spray and soil application by some residuals of sugar cane products (molasses and vinasses) treatments:

It is clear from Table (4) that foliar spray or soil application by some residuals of sugar cane products (molasses and vinasses) increased significantly fruit length, fruit diameter, fresh fruit weight, T.S.S in pepper fruits as well as dry matter \% in the both growing seasons expect the fruit flesh thickness which not reach to the significance level. The best treatments in this respect were obtained from the highest rates of molasses and vinasses compared with the other treatments. This results are in the same line with Şanlı et al. (2015) on sugar beet found that, Molasses applications significantly increased root yield and its quality compared to the control, at the same time soil applications were more effective than foliar applications for all parameters studied. So that molasses can be used effectively in order to increase sugar beet yield and its quality.

II -3 Effect of the interaction between mineral fertilization rates and foliar spray or soil application by some residuals of sugar cane products (molasses and vinasses) on the fruit characters of sweet pepper plants

The interactions between mineral fertilization rates and foliar spray or soil application by some residuals of sugar cane products on the fruit quality are shown in Table (5). The data indicate that fruit length and fresh fruit weight increased significantly in all treatments of the interactions at the high level of fertilization by $(100 \%)$ rate with soil application of molasses and vinasses at the rate of $60 \mathrm{~L} / \mathrm{fed}$ or $120 \mathrm{~L} / \mathrm{fed}$ followed by fertilization by $75 \%$ rate with soil application of molasses at $120 \mathrm{~L} / \mathrm{fed}$ in both growing seasons while, fruit 
的

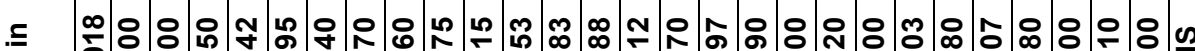

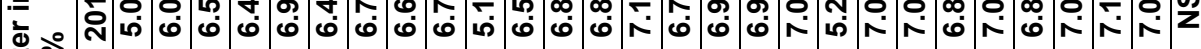
苋

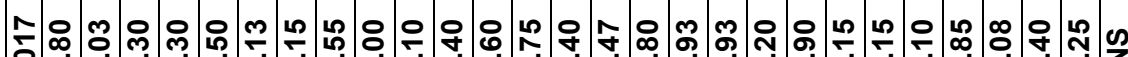

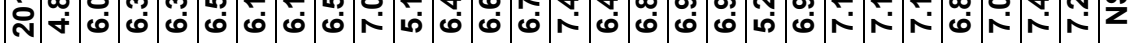

$\stackrel{0}{\text { है }}$

is $\stackrel{\infty}{\infty}$

즈 유

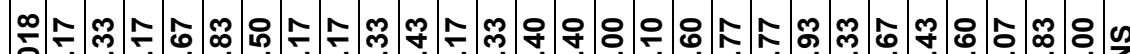

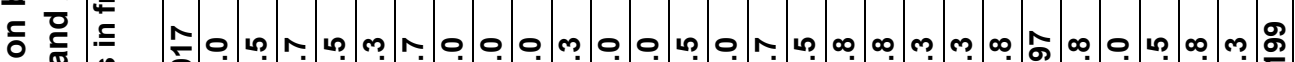

党 N

응

高 = ○

๖

은

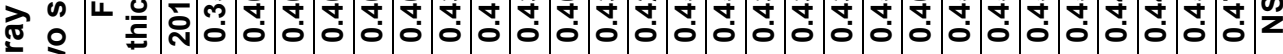

은

鱼

4

을

כิ

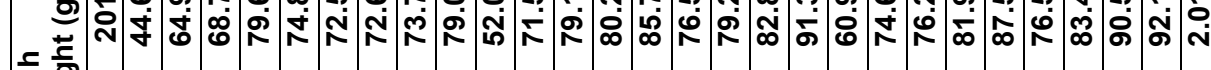

¿

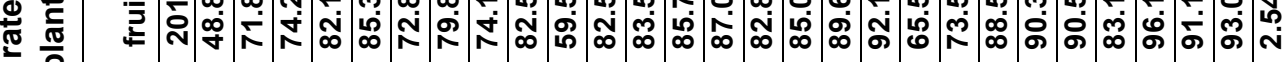

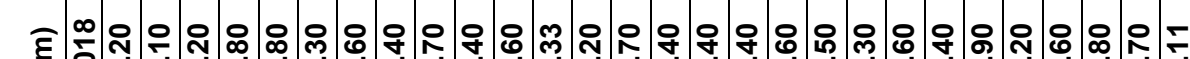

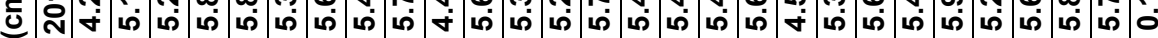

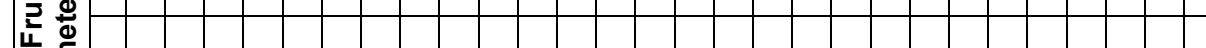

त)

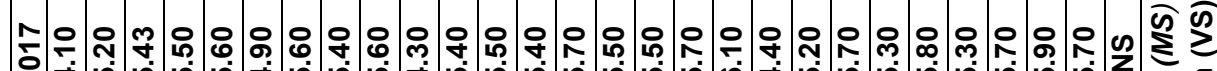

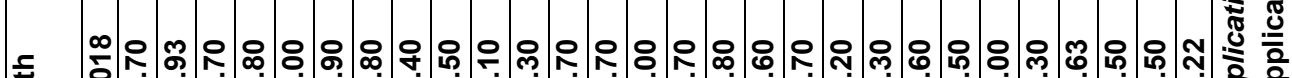

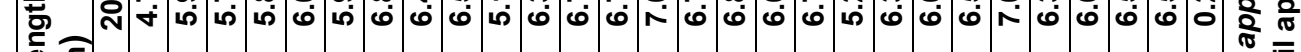

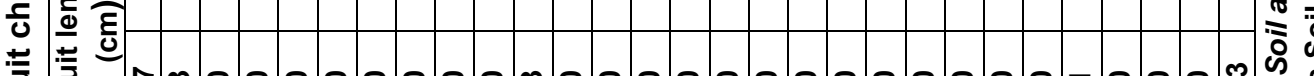

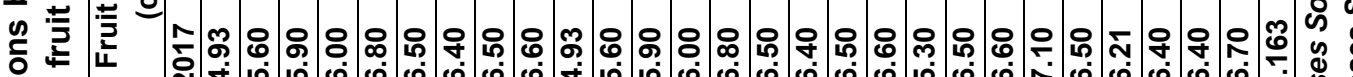

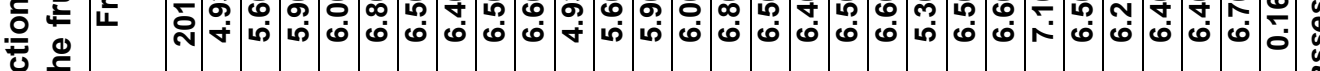

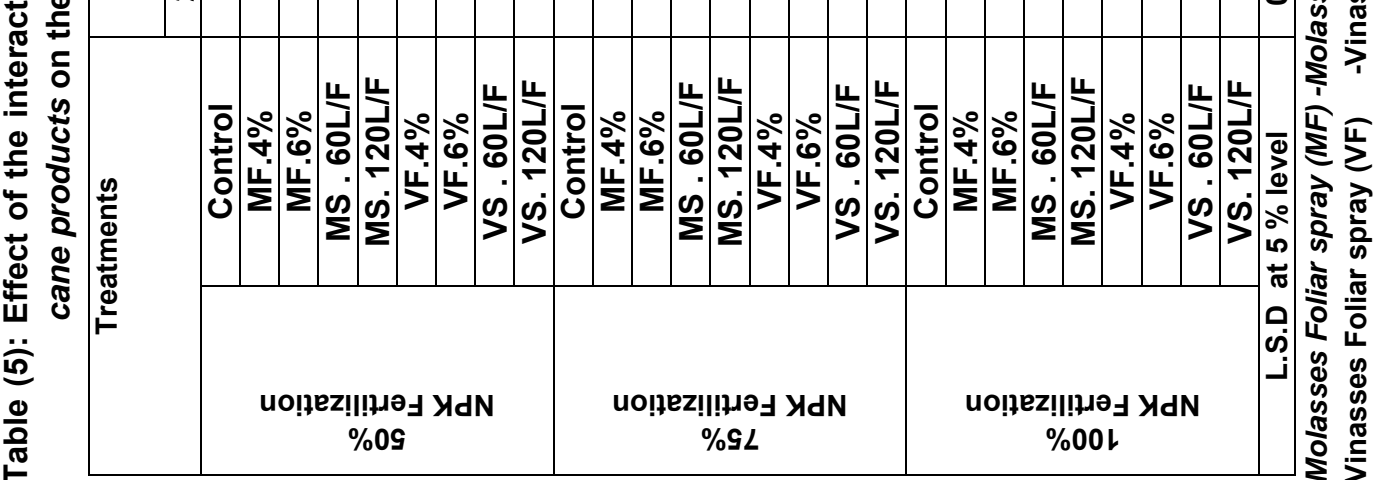


Mona S. Gaafar, et al.,

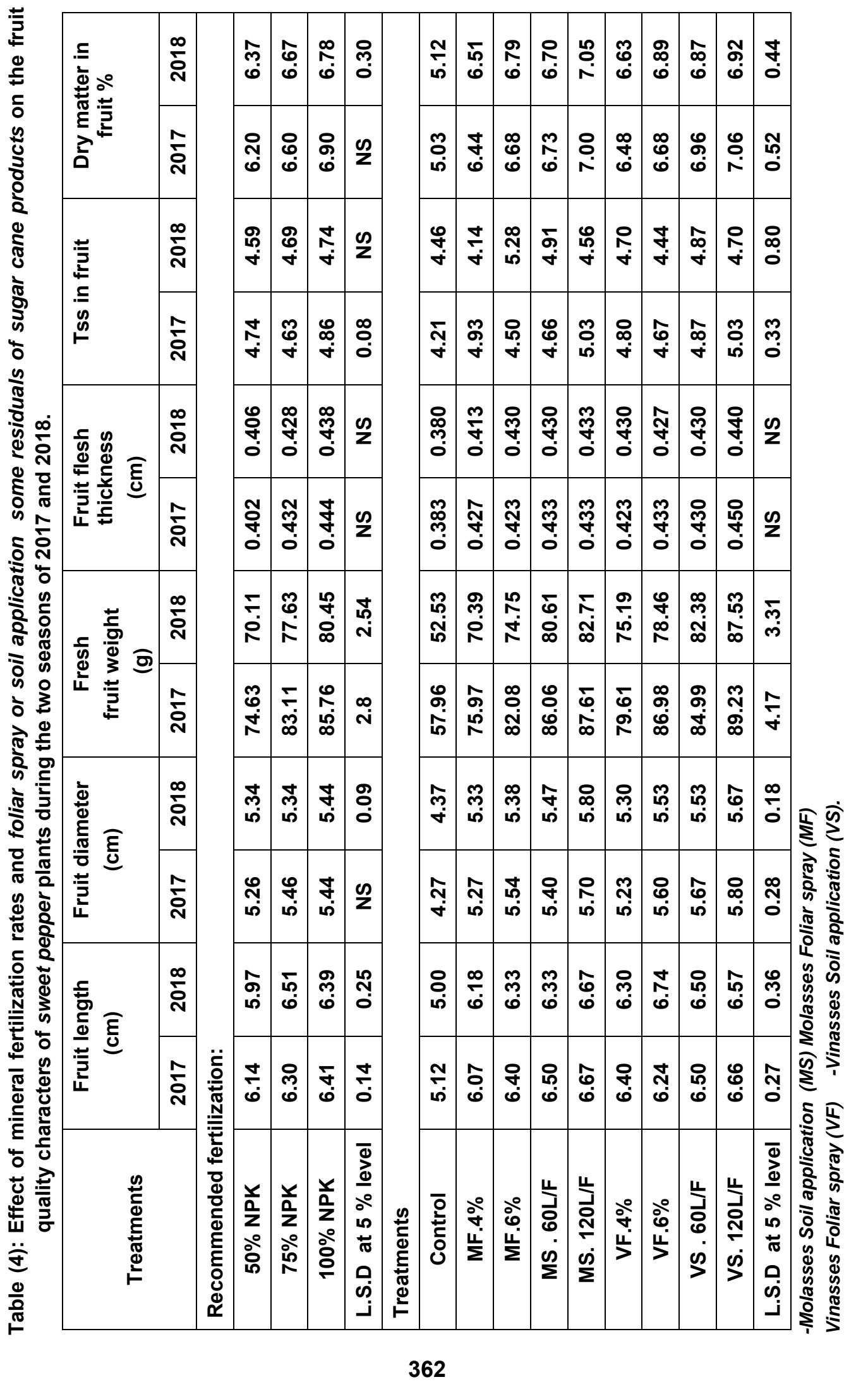


Mona S. Gaafar, et al.,

diameter and T.S.S of the fruits significantly increased in one season. But, it isn't notice significant in the fruit flesh thickness and dry matter in both seasons. The highest values were obtained by using soil application of molasses and vinasses with mineral fertilizer at rate of $100 \%$ and $75 \%$ from the recommended doses fertilization.

III- Effect of mineral fertilization rates and foliar spray or soil application by some residuals of sugar cane products (molasses and vinasses) on the total fruits yield of sweet pepper plants:

\section{III.1 Effect of mineral fertilization rates:}

According to the data in Table (6), the obtained results revealed that fruits number/plant, yield/plant $(\mathrm{kg})$ and total fruit yield (ton/fed) were significantly increased with the high rates of fertilizations $(75 \%$ and $100 \%)$ from the recommended doses of mineral fertilization of sweet pepper plants without significant level between them severally whereas, the increment reached to (11.076 -10.822 ton/fed.) and (12.01711.656 ton/fed.) with $75 \%$ and $100 \%$ comparing with the $50 \%$ which produced (8.154-7.859 ton/fed) at the two seasons respectively. The results are similar of that obtained by, Devi et al. (2002) who found that, better fruit yield of eggplant with the application of $120 \mathrm{~kg}$ (NPK) per hectare. Also Doss el al. (2015) revealed that the gradual increases of NPK fertilizer levels were accompanied with significant increases on sweet potato yield.

Table (6): Effect of mineral fertilization rates and foliar spray or soil application by residuals of some sugar cane products on the yield of sweet pepper plants during the two seasons of $2017-2018$

\begin{tabular}{|c|c|c|c|c|c|c|}
\hline \multirow[t]{2}{*}{ Treatments } & \multicolumn{2}{|c|}{ N. of fruits / plant } & \multicolumn{2}{|c|}{$\begin{array}{c}\text { Yield / plant } \\
(\mathbf{k g})\end{array}$} & \multicolumn{2}{|c|}{$\begin{array}{c}\text { Total fruit yield } \\
\text { (ton/fed) }\end{array}$} \\
\hline & 2017 & 2018 & 2017 & 2018 & 2017 & 2018 \\
\hline \multicolumn{7}{|c|}{ Recommended fertilization: } \\
\hline $50 \%$ NPK & 36.556 & 35.693 & 2.744 & 2.259 & 8.154 & 7.859 \\
\hline $75 \%$ NPK & 42.598 & 38.328 & 3.915 & 2.894 & 11.076 & 10.822 \\
\hline $100 \% \mathrm{NPK}$ & 41.370 & 39.447 & 3.269 & 2.945 & 12.017 & 11.656 \\
\hline L.S.D at $5 \%$ level & 3.3981 & 2.8199 & 0167 & 0.232 & 0.1691 & 0.4778 \\
\hline \multicolumn{7}{|l|}{ Treatments } \\
\hline Control & 31.210 & 29.567 & 1.785 & 1.573 & 6.563 & 6.092 \\
\hline MF.4\% & 39.500 & 37.610 & 3.094 & 2.522 & 10.347 & 10.006 \\
\hline MF.6\% & 41.377 & 38.273 & 3.323 & 2.658 & 10.708 & 10.550 \\
\hline MS. 60L/F & 38.333 & 36.680 & 3.447 & 2.606 & 10.828 & 10.586 \\
\hline MS. 120L/F & 41.567 & 39.567 & 3.909 & 3.218 & 11.244 & 10.973 \\
\hline VF.4\% & 39.333 & 40.040 & 3.075 & 2.740 & 10.551 & 10.227 \\
\hline VF.6\% & 41.667 & 39.773 & 3.647 & 2.982 & 10.847 & 10.480 \\
\hline VS. 60L/F & 42.333 & 38.600 & 3.393 & 2.845 & 11.182 & 10.812 \\
\hline VS. 120L/F & 46.250 & 40.293 & 4.113 & 3.150 & 11.470 & 11.283 \\
\hline L.S.D at $5 \%$ level & 3.2187 & 1.9519 & 0.203 & 0.152 & 0.5520 & 0.4226 \\
\hline
\end{tabular}

Molasses Foliar spray (MF) -Molasses Soil application (MS)

Vinasses Foliar spray (VF) -Vinasses Soil application (VS) 
III-2- Effect of foliar spray and soil application by some residuals of sugar cane products (molasses and vinasses) treatments:

The results in Table (6) clear that, each of foliar spray or soil application by some residuals of sugar cane products (molasses and vinasses) treatments at the rate of $(4 \%$ or $6 \%$ as foliar spray) or (60L/fed or $120 \mathrm{~L} /$ fed as soil application) recorded a significant increase in the fruits number/plant, the fruits yield/plant (kg) and the total fruits yield (ton/fed). Whereas, soil application of molasses and vinasses with the two rates (60 and $120 \mathrm{~L} / \mathrm{fed}$.) were more effective than foliar applications on the fruits number/plant, yield/plant $(\mathrm{kg})$ and total fruit yield (ton/fed). Also, foliar spray by molasses and vinasses with the highest rate $6 \%$ had a positive response compared to the other treatments in both seasons, These results are in the same line with those obtained by Li et al. (2008) and Mo et al. (2009) In China, which found that sugar cane treated with vinasse has increased its yields productivity. Also, In Spain, Madejón (2001) found that the yields of beets and maize were compared after treated with an organic compound based on vinasses or the mineral fertilizer, which showed that the crop production was similar in both treatments indicating that the utilization of vinasses is aviable alternative than mineral fertilizers. Moreover, Şanlı et al. (2015) on sugar beet studied the result of addition of different concentrations of molasses to the soil and to the plant leaves at different doses $(0,25,50,75$ and 100 $\mathrm{kg} / \mathrm{ha}) 3$ times during the vegetation period, they found that, Molasses applications significantly increased root yield compared to the control.
III-3- Effect of the interactions between mineral fertilization rates and foliar spray or soil application by some residuals of sugar cane products (molasses and vinasses) on the fruits yield of sweet pepper plants:

The data in Table (7) show the effects of the interactions between fertilization rates and different treatments of molasses or vinasses either as foliar spray or soil application on the fruits number/plant, yield/plant(kg) and total fruit yield (ton/fed). The previous treatments induced significant increases on yield of pepper fruits in the both seasons of the study compared with the control. All treatments either the soil application by molasses or vinasses at $60 \mathrm{~L} / \mathrm{fed}$. or $120 \mathrm{~L} / \mathrm{fed}$. or foliar spray by molasses and vinasses with the two rates i. e., $4 \%$ or $6 \%$ with the three rates of mineral fertilization $(50 \%, 75 \%$ or $100 \%$ ) had positive effect on the fruits number/plant, yield/plant(kg) and total fruit yield (ton/fed). The all interactions between mineral fertilizer rates at $\mathbf{7 5 \%}$ and the high levels of the two compounds i.e., molasses or vinasses on sweet pepper fruits yield and its components were superior without significant level between $\mathbf{7 5 \%}$ and $\mathbf{1 0 0 \%}$ of fertilizer rates. The results are similar of that obtained by. Gemtos et al. (1999) on wheat, Madejón et al. (2001) reported that, yields of beets and maize were compared after treatments with an organic compound based on vinasses or a mineral fertilizer, showed that, the crop production was similar in both treatments, but indicating that the utilization of vinasses is a viable alternative than the mineral fertilizers. 
Mona S. Gaafar, et al.,

Table (7): Effect of the interactions between mineral fertilization rates and foliar spray or soil application by some residuals of sugar cane products on the yield of sweet pepper plants during the two seasons of 2017 and 2018.

\begin{tabular}{|c|c|c|c|c|c|c|c|}
\hline \multirow{2}{*}{\multicolumn{2}{|c|}{ Treatments }} & \multicolumn{2}{|c|}{ N. of fruits / plant } & \multicolumn{2}{|c|}{$\begin{array}{c}\text { Yield / plant } \\
(\mathrm{kg})\end{array}$} & \multicolumn{2}{|c|}{$\begin{array}{c}\text { Total fruit yield } \\
\text { ( ton/fed) }\end{array}$} \\
\hline & & 2017 & 2018 & 2017 & 2018 & 2017 & 2018 \\
\hline \multirow{9}{*}{ 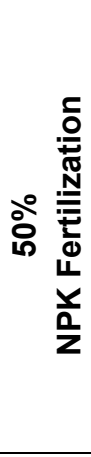 } & Control & 22.000 & 23.970 & 0.894 & 1.066 & 5.250 & 5.133 \\
\hline & MF.4\% & 35.000 & 35.100 & 2.511 & 1.931 & 7.910 & 7.730 \\
\hline & MF.6\% & 36.000 & 35.530 & 2.659 & 2.091 & 8.170 & 8.083 \\
\hline & MS . 60L/F & 36.500 & 34.430 & 3.109 & 2.401 & 8.630 & 8.313 \\
\hline & MS. 120L/F & 39.000 & 39.630 & 3.297 & 2.699 & 8.900 & 8.570 \\
\hline & VF.4\% & 40.000 & 41.500 & 2.707 & 2.596 & 8.250 & 7.593 \\
\hline & VF.6\% & 36.500 & 37.610 & 2.916 & 2.613 & 8.450 & 7.900 \\
\hline & VS. 60L/F & 39.000 & 35.750 & 2.899 & 2.178 & 8.750 & 8.473 \\
\hline & VS. 120L/F & 45.000 & 37.720 & 3.706 & 2.753 & 9.073 & 8.930 \\
\hline \multirow{9}{*}{ 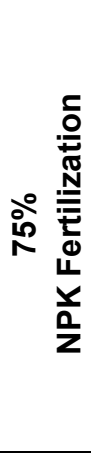 } & Control & 35.500 & 31.850 & 2.114 & 1.655 & 5.960 & 5.533 \\
\hline & MF.4\% & 43.500 & 38.590 & 4.017 & 3.105 & 11.400 & 10.850 \\
\hline & MF.6\% & 42.880 & 38.400 & 4.080 & 3.036 & 12.013 & 11.733 \\
\hline & MS . 60L/F & 40.500 & 35.250 & 4.100 & 2.105 & 11.473 & 11.273 \\
\hline & MS. 120L/F & 44.500 & 38.070 & 4.694 & 3.573 & 11.930 & 11.750 \\
\hline & VF.4\% & 38.000 & 40.320 & 3.150 & 2.886 & 11.267 & 11.183 \\
\hline & VF.6\% & 43.000 & 41.000 & 4.451 & 3.108 & 11.650 & 11.393 \\
\hline & VS . 60L/F & 46.000 & 39.550 & 3.662 & 3.020 & 11.917 & 11.743 \\
\hline & VS. 120L/F & 49.500 & 41.920 & 4.966 & 3.557 & 12.077 & 11.940 \\
\hline \multirow{9}{*}{ 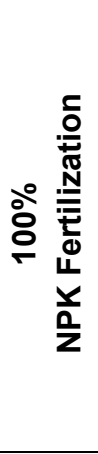 } & Control & 36.130 & 32.880 & 2.347 & 1.997 & 8.480 & 7.610 \\
\hline & MF.4\% & 40.000 & 39.140 & 2.753 & 2.529 & 11.730 & 11.437 \\
\hline & MF.6\% & 45.250 & 40.890 & 3.230 & 2.847 & 11.940 & 11.833 \\
\hline & MS . 60L/F & 38.000 & 40.360 & 3.131 & 3.311 & 12.380 & 12.170 \\
\hline & MS. 120L/F & 41.200 & 41.000 & 3.735 & 3.382 & 12.903 & 12.600 \\
\hline & VF.4\% & 40.000 & 38.300 & 3.367 & 2.737 & 12.137 & 11.903 \\
\hline & VF.6\% & 45.500 & 40.710 & 3.575 & 3.224 & 12.440 & 12.147 \\
\hline & VS. 60L/F & 42.000 & 40.500 & 3.617 & 3.337 & 12.880 & 12.220 \\
\hline & VS. 120L/F & 44.250 & 41.240 & 3.667 & 3.141 & 13.260 & 12.980 \\
\hline \multicolumn{2}{|c|}{ L.S.D at $5 \%$ level } & 1.9606 & 1.1889 & 0.183 & 0.092 & 0.3362 & 0.2574 \\
\hline
\end{tabular}

Molasses Foliar spray (MF) -Molasses Soil application (MS)

Vinasses Foliar spray (VF) -Vinasses Soil application (VS).

IV- Effect of mineral fertilization levels and foliar spray or soil application by some sugar residuals of cane products (molasses and vinasses) on chemical contents in the fruits and chlorophyll in the leaves of sweet pepper plants.

IV-1 Effect of mineral fertilization levels:

Data in Table (8) illustrate that, the effects of mineral fertilization rates on 
chemical contents, i. e., $\mathrm{N} \%, \mathrm{P} \%, \mathrm{~K} \%$ as well as VC in the fruits and the chlorophyll in the leaves of sweet pepper plants showed significant increase especially fertilization the plants with the highest rates $75 \%$ and $100 \%$ from recommended mineral fertilization rates of sweet pepper plants compared with $50 \%$ of recommended fertilization.

\section{IV-2- Effect of foliar spray or soil application by some residuals of sugar cane products (molasses and vinasses) treatments:}

Data in Table (8) reveale that, the effect of foliar spray or soil application by some residuals of sugar cane products (molasses or vinasses) on $\mathrm{N}, \mathrm{P}, \mathrm{K} \%$ and
VC content in the sweet pepper fruits and the chlorophyll in its leaves induced significant increases in all chemical constitutes in both growing seasons. All treatments either foliar spray or soil application by some residuals of sugar cane products gave positive response compared with the control. The results are in the same line with those obtained by Şanlı et al. (2015) which studied the effect of, addition of different concentrations of molasses to the soil and to the plant leaves at different doses $(0,25,50,75$ and $100 \mathrm{~kg} / \mathrm{ha}) 3$ times during the vegetation period they found that, molasses applications significantly increased the quality of sugar beet compared to the control.

Table (8): Effect of mineral fertilization rates and foliar spray or soil application by some residuals of sugar cane products on chemical contents in fruits and chlorophyll in leaves of sweet pepper plants during the two seasons of 2017 and 2018.

\begin{tabular}{|c|c|c|c|c|c|c|c|c|c|c|}
\hline \multirow[t]{2}{*}{ Treatments } & \multicolumn{2}{|c|}{ N\% } & \multicolumn{2}{|c|}{$\mathrm{P} \%$} & \multicolumn{2}{|c|}{$\mathrm{K} \%$} & \multicolumn{2}{|c|}{ VC( mg) } & \multicolumn{2}{|c|}{$\begin{array}{c}\text { Chlorophyll } \\
\text { SPAD }\end{array}$} \\
\hline & 2017 & 2018 & 2017 & 2018 & 2017 & 2018 & 2017 & 2018 & 2017 & 2018 \\
\hline \multicolumn{11}{|c|}{ Recommended fertilization: } \\
\hline $50 \%$ NPK & 2.45 & 2.56 & 0.371 & 0.366 & 4.580 & 4.529 & 160.63 & 159.91 & 77.34 & 76.16 \\
\hline $75 \%$ NPK & 2.66 & 2.73 & 0.368 & 0.379 & 4.709 & 4.734 & 181.68 & 182.25 & 79.51 & 77.87 \\
\hline $100 \%$ NPK & 2.68 & 2.86 & 0.384 & 0.391 & 4.763 & 4.869 & 195.27 & 195.09 & 80.21 & 79.07 \\
\hline L.S.D at $\mathbf{5 \%}$ level & 0.01 & 0.02 & 0.011 & 0.017 & 0.084 & 0.011 & 0.46 & 0.96 & 0.93 & 1.37 \\
\hline \multicolumn{11}{|c|}{ Treatments } \\
\hline Control & 1.81 & 1.90 & 0.3100 & 0.3000 & 3.287 & 3.330 & 147.60 & 144.08 & 73.20 & 74.17 \\
\hline MF.4\% & 2.50 & 2.61 & 0.3733 & 0.3733 & 4.607 & 4.533 & 173.57 & 174.03 & 78.86 & 76.91 \\
\hline MF.6\% & 2.68 & 2.67 & 0.3800 & 0.3700 & 4.744 & 4.767 & 179.70 & 181.03 & 78.24 & 77.54 \\
\hline MS . 60L/F & 2.68 & 2.79 & 0.3833 & 0.3833 & 4.880 & 4.880 & 185.77 & 186.43 & 80.56 & 80.87 \\
\hline MS. 120L/F & 2.85 & 2.85 & 0.3900 & 0.3933 & 4.853 & 4.980 & 197.73 & 193.30 & 79.70 & 77.77 \\
\hline VF.4\% & 2.64 & 2.79 & 0.3644 & 0.3867 & 4.803 & 4.827 & 172.47 & 172.50 & 79.80 & 77.00 \\
\hline VF.6\% & 2.74 & 2.85 & 0.3667 & 0.3900 & 4.968 & 4.947 & 181.30 & 182.47 & 80.32 & 76.46 \\
\hline VS . 60L/F & 2.85 & 2.92 & 0.4000 & 0.4000 & 4.933 & 5.043 & 179.33 & 182.53 & 80.07 & 79.47 \\
\hline VS. 120L/F & 2.59 & 3.09 & 0.4022 & 0.4089 & 5.080 & 5.090 & 195.27 & 195.37 & 80.42 & 79.11 \\
\hline L.S.D at $\mathbf{5 \%}$ level & 0.02 & 0.01 & 0.018 & 0.02 & 0.016 & 0.016 & 2.25 & 2.10 & 1.85 & 1.87 \\
\hline
\end{tabular}

Molasses Foliar spray (MF) -Molasses Soil application (MS)

Vinasse Foliar spray (VF) -Vinasse Soil application (VS). 
Mona S. Gaafar, et al.,

IV-3- Effect of the interactions between mineral fertilization rates and foliar spray or soil application by some residuals of sugar cane products (molasses and vinasses) on chemical contents in the fruits and the chlorophyll in the leaves of sweet pepper.

The interactions between mineral fertilization rates and foliar spray or soil application by some residuals of sugar cane products on $\mathrm{N}, \mathrm{P}, \mathrm{K} \%$ and $\mathrm{VC}$ in sweet pepper fruits and the chlorophyll in its leaves as shown in Table (9). The obtained results show clearly that, $\mathrm{K} \%$ and VC in the fruits and the chlorophyll in the leaves were significantly increased in both growing seasons in addition of $\mathrm{N} \%$ in the first season.

Table (9): Effect of the interactions between mineral fertilization rates and foliar spray or soil application by some residuals of sugar cane products on chemical contents in fruits and chlorophyll in leaves of sweet pepper plants during the two seasons of 2017 and 2018.

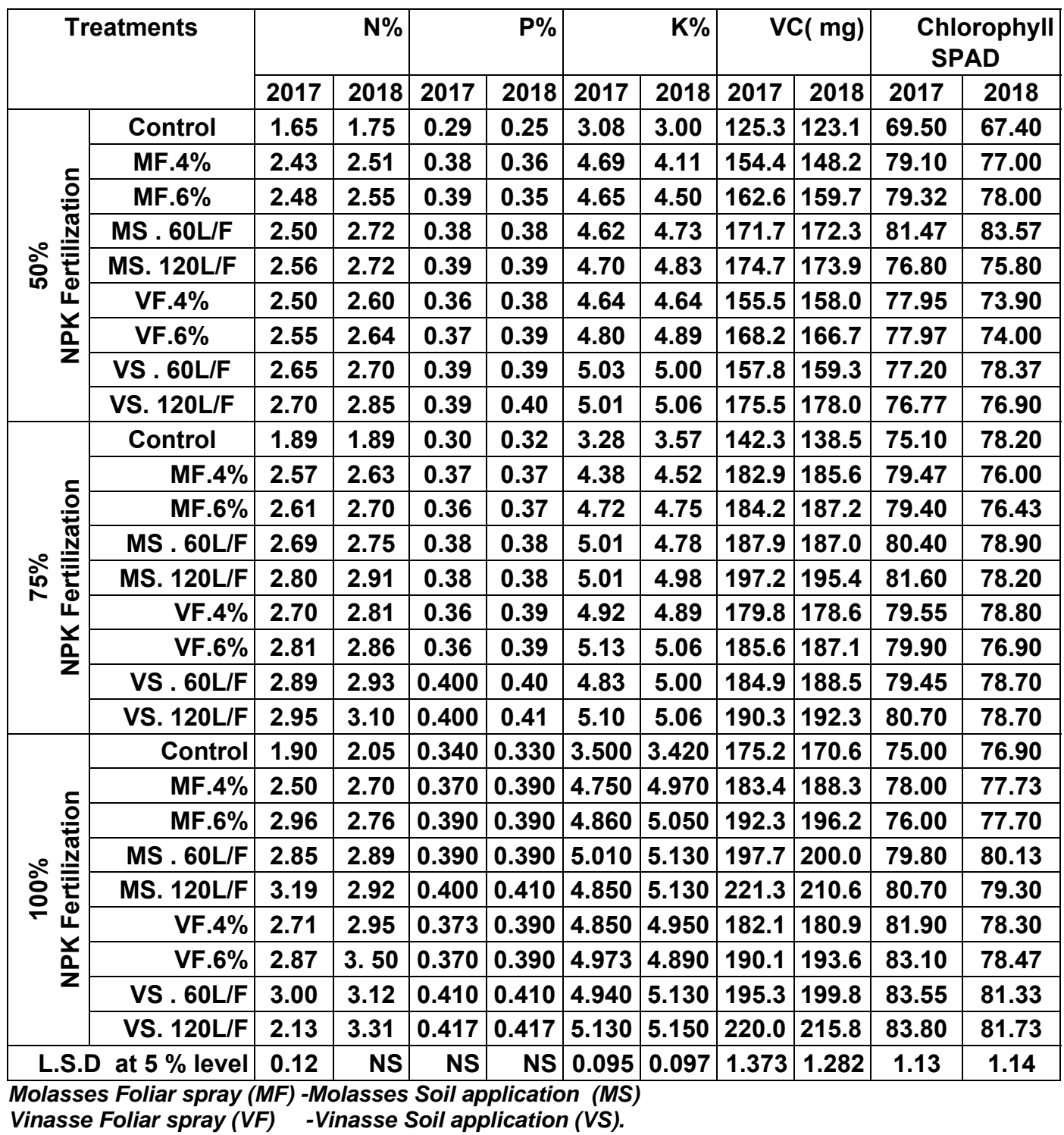




\section{Economic returns:}

The economic performance of sweet pepper plants as affected by different levels of mineral fertilization and foliar spray or soil application by some residuals of sugar cane products (molasses or vinasses) are demonstrated in Table (10). The results reveal that foliar spray by vinasses or molasses at $6 \%$ with the rates of $75 \%$ from recommended mineral fertilization dose followed by the soil application by vinasses at $60 \mathrm{~L} / \mathrm{fed}$ or $120 \mathrm{~L} / \mathrm{fed}$. as well as molasses at $120 \mathrm{~L} /$ fed under the ratesof $100 \%$ from recommended mineral fertilization gave the highest benefit cost ratio in comparison with other treatments. The results are in the same line with those obtained by Labib et al. (2012) on potato, Kamal et al. (2013) on sweet pepper, ElShimi and Byan (2015) on eggplants and El-Shimi et al. (2015) on sweet pepper; they mentioned that using the naturally deposited materials instead of mineral fertilizers would be very beneficial for both farmers as well as the national authorities which subsidize the high costs of mineral fertilizers.

Table (10): Economic performance of sweet pepper plants as affected by some fertilization rates and foliar spray or soil application by some residuals of sugar cane products (molasses and vinasse) during the average of two seasons, 2017 and 2018.

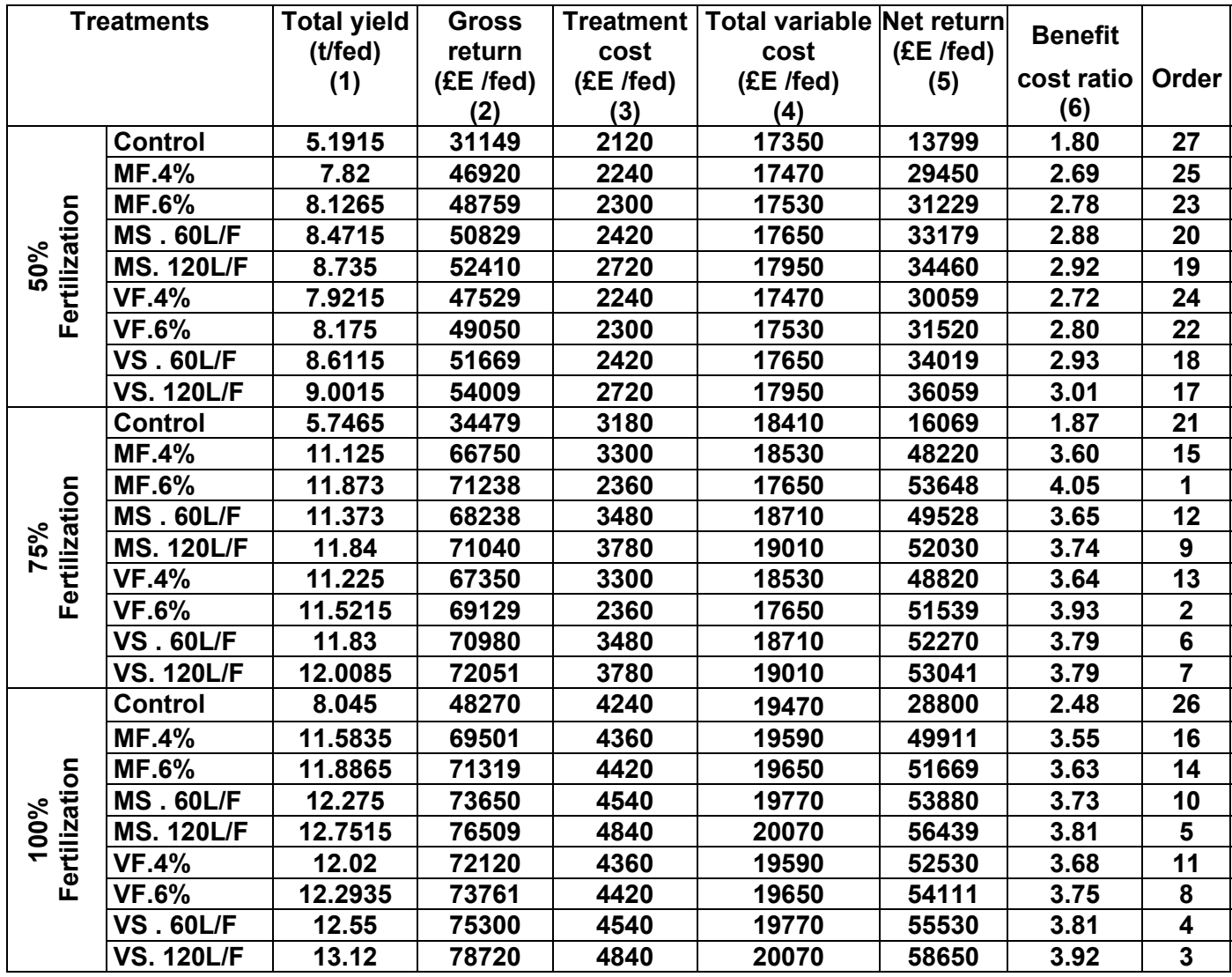

1)Total yield (t/fed) as average of two seasons,(2) Gross return as total yield (t/fed) $\times 6000 £ E$ Iton,(3) Treatment cost as fertilizers cost + Molasses or vinasses cost as the following prices : Molasses $=5 £ E$, vinasses $=5 £ E / L$, super phosphate $=75 £ E / 50 \mathrm{~kg}$, potassium sulphate $=300 £ E / 25$ $\mathrm{kg}$, Ammonium sulphate $=150 £ \mathrm{E} / 50 \mathrm{~kg}$,(4) Total variable cost (£E /fed) including Treatment cost plus agricultural practices which equal nearly $15230 £ \mathrm{E} / \mathrm{fed}),(5)=(2)-(4),(6)=(2) /(4)$. 


\section{Conclusion}

According to the previous results, it can concluded that, fertilizing sweet pepper plants by $100 \%$ or $75 \%$ from the mineral fertilizer recommendation and spraying the plants by molasses of $6 \%$ as well as adding molasses or vinasses at $120 \mathrm{~L} / \mathrm{fed}$ as soil application recognized the favorable economically significant values on the vegetative growth and fruits yield with best quality. This mean that decreasing the quantity of mineral fertilization by $25 \%$ without any reduction effect on sweet pepper fruit yield, at the same time, it increased the yield with high net income to the growers.

\section{REFERENCES}

Boardman, A. E., D. H. Greenberg, A. R. Vining and D. L. Weimer (2001). Costbenefit analysis. Concepts and practice. $2^{\text {nd }}$ ed.Prentice Hall, Upper Saddle River.

Bremner, J. M. and C. S. Mulvaney (1982). Total nitrogen. In: Pag, A. L., R.H.Miller and D. R. Keeny (Eds).Methods of soil analysis. Part2, Amer. Soc. Agron. Madison, W.I.USA, 595-624.

Chandraju, S., H.C. Basavaraju and C.S. Chidankumar (2008). Investigation of impact of Irrigation of distillery on the nutrients of cabbage and mint leaf. Indian Sugar, 39(19):15-28.

Chapman, H. D. and F. P. Pratt (1961). Methods of Analysis for Soils Plant and Water. Univ. of California Div. of Agric. Sci. pp120-127.

Devi, H.H., T.K. Maity, N.C. Paria and U. Thapa (2002). Response of brinjal to different sources of nitrogen. J.Veg. Sci. 29(1):45-47.

Doss, M. M., S. M. El-Araby, M. A. Abd ElFattah and A. A. Helaly (2015). The Impact of Spraying with Different Concentrations of Seaweed Extract under Different Levels of Mineral NPK Fertilizers on Sweet Potato (Ipomoea batatas (L.)) Plants.Alex. J. Agric. Res Vol. 60, No.3, pp. 163-172

EL-Shimi -Nahed, M.M and A.I. ByanUsrya (2015). Effect of adding charcoal as natural organic matter and fertilizer levels recommendation on the growth and yield of eggplant plants. Egypt. J. Appl. Sci., 30 (4): 107-125.

EL-Shimi -Nahed, M.M , El-Sayeda, H. M. El-Badawy and Hager I. Tolba (2015). Response of sweet pepper plants to some organic and bio-fertilizers and its effect on fruit yield and quality. Meddle East J. of Agric. Res. 4 (3): 435- 445.

Gemtos, T. A., N. Chouliaras and S. Marakis, (1999)."Vinasse rate,

time of application and compaction effect on soil properties and durum wheat crop," Journal of Agricultural Engineering Research, vol. 73, no. 3, pp. 283-296.

Honma T., A. Kaneko, H. Ohba and T. Ohyama (2012). Effect of application of molasses to paddy soil on the concentration of cadmium and arsenic in rice grain. Soil Science and Plant Nutrition, 58(2):255-260.

Jiang, Z. P., Y. R. Li and G. P.Wei (2012). "Effect of long-term vinasses application on physico-chemical properties of sugarcane field soils, Sugar Tech, vol. 14, no. 4, pp. 412417.

Kamal, A.M., A.A. El-Awady and W.A. Ramadan (2013). Acomparative study of som natural potassium fertilizer sources on sweet pepper growth,mineral status,productivity and storability.Hort.J.Suez Canal .Univ.1:387-401.

Labib, B.F., T.K. Gabour, I.S. Rahim and M.M. Wahba (2012). Effect of potassium bearing rock on the growth and quality of potato crop. J. Agric. Bio. Sustainable Development, 4(1): 715. 
Laime, E. M. O., P. D. Fernandes, D. C. S. Oliveira and E. A. Freire (2011). "Possibilidades tecnol'ogicas para a destinac, ¿ao da vinhac,a: uma revis ao," Revista Tr'opica, vol. 5, no. 3, p. 16.

Li, Y. R., Q. Z. Zhu and W. Z. Wang (2008). "Multiple location experiment of technique system for direct rational application of vinasse from cane mill in sugarcane fields," Southwest China Journal of Agricultural Sciences, vol. 21, no. 3, pp. 749-756.

Madej'on, E., R. L'opez, J. M. Murillo and F. Cabrera (2001). "Agricultural use of three (sugar-beet) vinasse composts: effect on crops and chemical properties of a Cambisol soil in the Guadalquivir river valley (SW Spain)," Agriculture, Ecosystems and Environment, vol. 84, no. 1, pp. 55-65.

Mengel, K. and Kirkby (1982). Principles of plant Nutrition, 3rdedn. International Potash Institule, Bern, Swilzcrland.

Mo, Y. C., Y. P. Ye, Q. Liang and Y. R. Li (2009). "Effects of vinasse on the quality of sugarcane and key enzymes in sucrose synthesis," Southwest China Journal of Agricultural Sciences, vol. 22, no. 1, pp. 55-59.

Mohammadi Torkashvand A. and A.R. Barimvandi (2008). The effects of sugar cane molasses on calcareous soil chemical characteristics. Pajouhesn-Va Sazandegi Winter, 21(4): 47- 53.

Olsen, S. R. and L. E. Sommers (1982). Phosphorus. In:Page, A. L.; R. H. Miller and D. R. Keeney (Eds). Methods of soil analysis. Part 2 Amer. Soc. Agron. Madison, W. I. USA, 403430.

Paulino, A. F., C. C. Medina, C. R. P. Robaina and R. A. Laurani (2002). "Produc, oes agr'ıcola e industrial de cana-de-ac, ucar submetida a doses de vinhac,a," Semina: Ci^encias Agr'arias, vol. 23, no. 2, pp. 145-150.

Piper, G. S. (1950). "Soil and Plant Analysis". Inter. Sci. Publisher Inc. New York. USA.

Pujar S. S. (1995). Effect of distillery effluent irrigation on growth, yield and quality of crops. M.Sc. (Agri.) Thesis, University of Agricultural Sciences, Dharwad, India (Unpublished).

Rajput, J. C. and Y. R. Poruleker (1998). Capsicum in Handbook of vegetable science and technology (D.K. Salunkhe and S.S. Kadam, eds.) Marcel Dekker, Inc. New York, p.721729.

Ranganna, C. (1979). Manual of analysis of fruit vegetable products. Tatame. Graw Hill publishing company limited New Delhi (2nd ed). pp.63-71.

Rani, R. and M. M. Vastava (1990). Ecophysiological response of pisum sativum and citrus Maxima to distillery effluents. Intl. J. Eco Environ. Sci., pp: 16-23.

Renato, M. P., G. Caione and C. N. S. Campos (2013). Filter Cake and Vinasse as Fertilizers Contributing to Conservation Agriculture Applied and Environmental Soil Science Volume 2013, Article ID 581984, 8 pages.

Resende, A. S., A. Santos and R. P. Xavier (2006). "Efeito da queima da palhada da cana-de-açúcar e de aplicações de vinhaça e adubo nitrogenado em características tecnológicas da cultura," Revista Brasileira de Ciência do Solo, vol. 30, no. 6, pp. 937-941.

Roberts, T. L. (2001). Fall Fertilization Facts: Opportunities and Considerations. Foundation for Agronomic Research (FAR). 655 Engineering Drive, Suite 110.2pp

Samavat, S. and S. Samavat (2014). The effects of fulvic acid and sugar cane molasses on yield and qualities of 
Mona S. Gaafar, et al.,

tomato. International Research Journal of Applied and Basic Sciences, 8(3): 266-268.

Şanlı, A., T. Karadogan and B. Tosun (2015). "The Effects of Sugar Beet Molasses Applications on Root Yield and Sugar Content of Sugar Beet(Beta vulgaris L.) Journal of Field Crops Central Research Institute, 24 (2): 103108.

Silva, A. J. N., M. S. V. Cabeda, F. G. Carvalho and J. F.W. F. Lima (2006). "Alterac, oes f'isicas e qu'ımicas de um Argissolo amarelo sob diferentes sistemas de uso e manejo," Revista Brasileira de Engenharia Agr'icola e Ambiental, vol. 10, no. 1, pp. 76-83.

Silva, M. A. S. N. P. Griebeler and L. C. Borges (2007). "Uso de e impactos nas propriedades do solo e lenc,ol fre'atico," Revista vinhac,a Brasileira de Engenharia Agr'ıcola e Ambiental, vol. 11, no. 1, pp. 108-114.

Snedercor, G. W. and W. G. Cochran (1980). Statistial Methoods, $7^{\text {th }}$ Ed., The lowa state Univ., Press, Ames., lowa, U. S. A.

Wallace, D. H. and H. M. Munger (1965). Studies of the physiological basis for yield differences.1. growth and analysis of six dry bean varieties. Crop Sci., 5: 343-348.

Zolin, C. A., J. Paulino, A. Bertonha, P. S. L. Freitas and M. V. Folegatti (2011). "Estudo explorat'orio do uso da vinhac, a ao longo do tempo. I. caracter' Isticas do solo," Revista Brasileira de Engenharia Agr'icola e Ambiental, vol. 15, no. 1, pp. 22-28. 
تأثير الرش الورقى و الاضافة الارضية لبعض مخلفات منتجات تصنيع قصب السكر (المولاس و الفيناس) مع مستويات من التسميد المعدنى على نمو

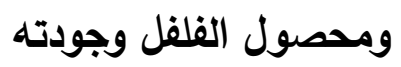

منى سيد جعفر ، ناهد محمد مهذى الثيمى، محمود محمد حلمى الثي أقسام بحوث الخضر - معهد بحوث البساتين-مركز البحوث الززاعية- الجيزة -مصر"

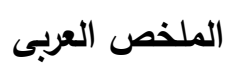
أجريت هذه الدارسة لتحديد تاثير بعض مخلفات منتجات قصب السكر ، مثل المولاس و الفيناس على محصول الفلفل

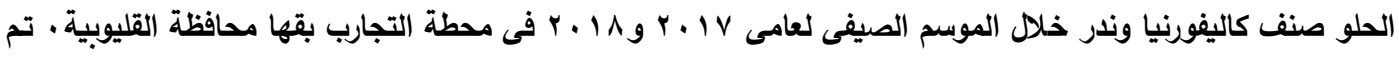

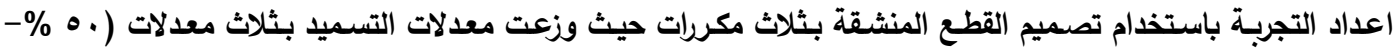

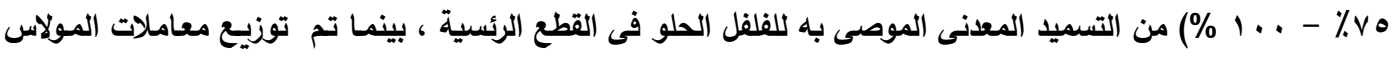

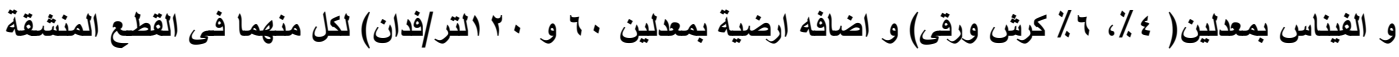

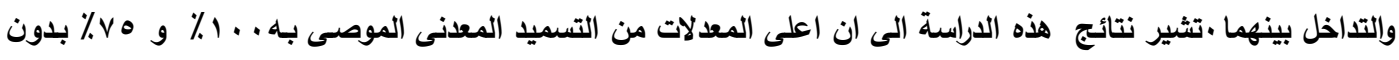

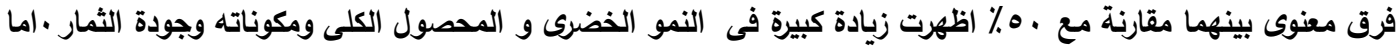

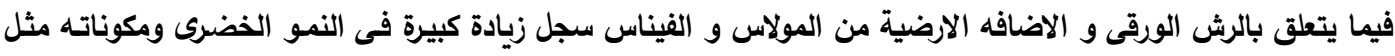

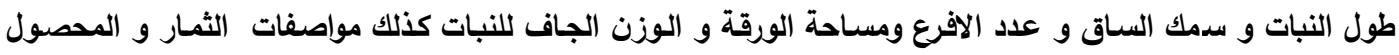

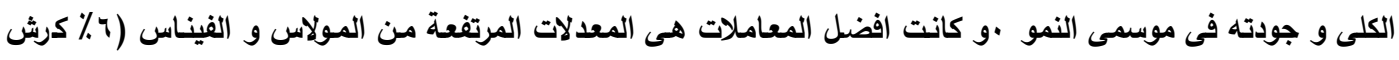

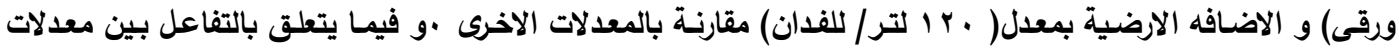

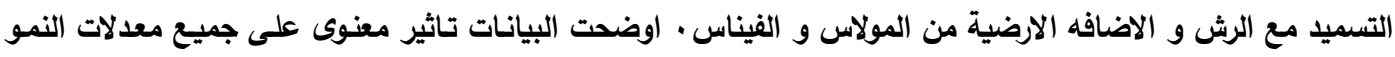

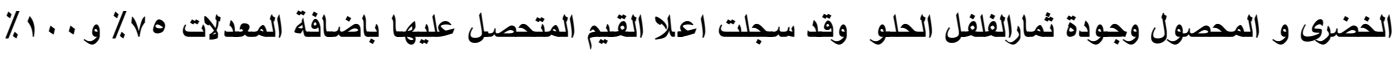

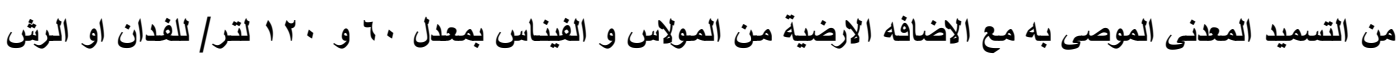

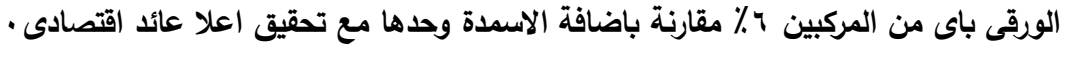

